\title{
Market Structure and Performance of Commercial Banks: Empirical Evidence from Nepal
}

\begin{abstract}
Kripa Kunwar ${ }^{1}$
Abstract

The study attempts to examine the relationship of market structure variable with the performance of Nepalese commercial banks over the period 2011-2015 using causal research design. The stratified sampling technique has been employed to select sample banks which include 10 commercial banks comprising 5 joint venture and 5 local private banks. A pooled OLS model is specified, and then the indicators of market structure are used as explanatory variables in the regression model. Study results have shown that market concentration has had a negative and significant impact on the performance of the Nepalese commercial banks. Where the Herfindahl-Hirschman index (HHI) is used the market shares as the main variable to measure the concentration (CONC). Empirical results revealed that lower the market concentration higher will be the performance of the bank. On the other hand, study concluded that market power has positive influence on profitability. The Data Envelopment Analysis (DEA) method was used to assess the efficiency scores. On the contrary, empirical results indicated that there is no relationship between the bank's efficiency and performance in Nepalese commercial banks. As far as the ownership structure is concerned, study found that, ROA differences depend on bank ownership types. Study concluded that performance of the joint venture banks is better than local private banks in sample period.
\end{abstract}

Keywords: Bank Efficiency, Bank Performance, Market Power, Market Structure

\section{Introduction}

Market structure of the banking industry refers to the number of banks in the market, their market share and other features which affect the level of competition in the market. As well as market structure influences the bank's behavior whether it is efficient, and level of profits it can generate. Considering market structures, modern theory also looks at the firm's performance and the level of contestability in the market. The theory of Market Power (MP) and the theory of Efficient Structure (ES) explain the relationship between the market structure and performance of the bank. Furthermore, StructureConduct-Performance hypothesis (SCP) and Relative Market Power hypothesis (RMP) are concerned with MP theory similarly $\mathrm{x}$-efficiency (XE) and scale efficiency (SE) hypothesis explain the ES theory.

Under structure conduct performance (SCP) analyzing paradigm, the market structure affects performance. $\mathrm{Fu}$ and Heffernan (2009), Ayadi \& Ellouze (2013) explain that according to SCP hypothesis the more concentrated the banking system, the more it is able to earn higher profits and thereafter the more it efficient will be. Under RMP hypothesis the banks with a large market share and diversified products that might exercise their market power to determine prices and make profits. As a result, individual market shares accurately determine market power and market imperfections (Mensi \& Zouari, 2010). Berger (1995), Mensi \& Zouari (2010) explain that under the x-efficiency hypothesis, the costs incurred by banks with efficient management and/or technologies are lower resulting in higher profitability. The better banks x-efficiency is, larger are market shares and higher is concentration. Under the efficiency hypothesis, the difference in performance between two firms is not due to differences in management quality, but to differences at 
the level of scale efficiency. Banks costs lower than their competitors result in higher profitability. These banks may acquire extended market shares which increases market concentration.

The history of modern banking practices in Nepal has started after the establishment of Nepal bank Limited in the year 1937. Similarly Nepalese financial system got the new dimension after the establishment of Nepal Rastra Bank as the central bank in the year 1956. With the initiation of financial sector liberalization process during 1980s many joint venture and local private banks entered into the market. Banking industry of Nepal has been characterized by strong competition with the continual increase in the number of banks. After the entry of joint venture banks and then the mushrooming of Nepalese private banks with the new definition of and approach to banking, the whole banking industry in general, and the one-time monopolist governmentowned banks in particular are under the pressure to continue their competitive position (Thapa, 2010). As the apex body of financial institution, Nepal Rastra bank (NRB) regulates the activities of financial institution; provide guidelines and suggestion to make them more competitive and efficient. Under the policy adopted by NRB many banks which are operating in Nepal are going for merger and acquisition. As on October 2016, there are 28 commercial banks in Nepal. Out of these 7 are joint venture banks and 3 are state-owned and remaining are local private bank.

Financial system of Nepal is highly dominated by banking sector, particularly commercial banks. As a result the economic stability and growth of the country largely depend on the banking industry. That's why the policy should focus on banking sector development by enhancing its quality in Nepal (Kharel \& Pokhrel, 2012). Market structure of the bank is long consider as the main factor for the development of banking industry that influences the competitiveness of the banking system and companies' access to funding and thereby their investment (González, 2009).
Pradhan and Gajurel (2011) concluded that Nepalese banking industry is becoming less concentrated and more competitive in recent years. Scenario of banking industry in Nepal is ever changing due to the changing government policy. As a result performances of the banks are affected. This study has been designed to examine the structure-performance relationship of the Nepalese commercial banks. There have been extensive research works on the relationship between

Market Structure and Performance of the bank. Review of large number of previous studies suggests that market structure of banking industry can influence the performance of the banks. Similarly past studies and theory recommend that efficiency and market structure are the key factors for the survival in complex environment in banking industries where market concentration and market share are regarded as the index of market structure of the bank. Herfindahl-Hirshman index (HHI) is used to measure the market concentration and competitiveness (Ayadi \& Ellouze, 2013). Likewise Data Envelopment Analysis (DEA) method is used to assess the efficiency scores. Looking at current scenario of Nepalese banking industry, the present study has raised the following research question:

i. Is there a relationship between market structure variable and performance of commercial banks?

On the basis of the above mentioned background and statement of the problem following objective has been set for the study:

i. To examine the relationship of market structure variable with the performance of commercial banks.

\section{Literature Review}

Tan and Floros (2013) examined the relationship between (i) risk and market power, and (ii) efficiency/ productivity and market power. Study reveals that higher efficiency leads to higher market power for Chinese banks. Furthermore, researcher found that Chinese banks with higher volumes of nontraditional activities normally have lower market power. 
Ayadi and Ellouze (2013) tested the theory of Market Power (MP) and the theory of Efficient Structure (ES) to explain the relationship between bank performance and market structure. Regarding the theory of MP, it includes two hypotheses: Structure-Conduct-Performance hypothesis (SCP) and Relative Market Power hypothesis (RMP). With regard to the theory (ES), it has also two hypotheses: the hypothesis of $\mathrm{x}$-efficiency (ESX) and the hypothesis of scale efficiency (ESS). And Results showed that $\mathrm{x}$-efficiency has had a positive and significant effect on the performance of the Tunisian commercial banks as well as the hypothesis of $\mathrm{x}$-efficiency.

Zhengchao and Qin (2012) analyzed the relationship between Chinese banking market structure and performance. Researcher employed the methodology of SCP (structure-conduct-performance), introduce macro economics factors into regression model and use the panel data of 14 major commercial banks in China Mainland from 2000 to 2010. The results showed that China banking market is still in the oligopoly status, and the oligopoly degree reduces gradually over time. The oligopoly degree has a negative correlation with the performance which was measured by HerfindahlHirschman Index ( HHI ). The deposit-loan ratio and the capital adequacy ratio have both positive correlations with the performance.

Ugwunta, Ani, Ugwuanyi, and Ugwu (2012) measured the market structure and competition in the consolidated Nigerian banking industry, as well as investigated the impact of the banking sector structure on bank performance. Significant findings included that the Nigerian banking sector is oligopolistic in structure and that market concentration positively and significantly impacts on bank performance. These results suggested that market concentration is a major determinant of bank profitability in Nigeria.

Pradhan and Gajurel (2011) tested the structure performance hypotheses in the context of Nepalese banking industry for the period of 2001-2009 under the Berger and Hannan (1993) empirical framework. The empirical results suggested that traditional structure- conduct-performance hypothesis and quite life hypothesis are better explaining concentration-profitability relation in Nepalese banking industry. Similarly study found that there is weak support for efficiency structure hypotheses.

Thapa (2010) examined strategy-performance relationship in the Nepalese banks. The findings of this study have suggested that there exists a positive relationship between competitive strategies pursued by the banks and their organizational performance. The highest performance seemed to be correlated with cost leadership (cost reduction, operating efficiency and offering competitive prices) strategy, followed by differentiation (in particular through unique and wider range of services offered) strategy, and market-focus strategy respectively. It is further observed that banks have preferred more to pursue the combination of costleadership and differentiation strategies than the marketfocus strategy to attain their higher performance.

Mensi and Zouari (2010) investigated the market structure-performance relationship within the Tunisian banking system. They distinguished between two theories, namely the Efficient Structure Theory and Market Power Theory using the Data Envelopment Analysis Method, and estimated efficiency measures under X-efficiency, Technical Efficiency, Scale Efficiency and Allocative Efficiency. The empirical investigation is conducted on profit and price regressions for a sample of 10 commercial banks. The results rejected the SCP and Quite life hypotheses under the market power theory but retain the RMP hypotheses. Also, all the hypotheses under Efficient Structure theory are rejected.

\section{Hypotheses Development}

The theory of Market Power (MP) and the theory of Efficient Structure (ES) explain the relationship between market structure and performance of the bank. Regarding the theory of MP, it includes two hypotheses: StructureConduct-Performance hypothesis (SCP) and Relative Market Power hypothesis (RMP) (Ayadi Ellouze, 2013). Similarly ES theory also includes two hypothesis $\mathrm{x}$-efficiency and scale efficiency. According to structure conduct performance (SCP) analyzing paradigm, the 
market structure affects performance. Ayadi \& Ellouze (2013) explain that under SCP hypothesis the more concentrated the banking system, the more it is able to earn higher profits. Herfindahl-Hirschman Index (HHI) can reflect the comprehensive condition of the whole banking industry that represents market structure. Moreover, the market concentration rate is usually utilized to represent market structure (Zhengchao \& Qin, 2012). Bamakhramah (1992) observed a negative correlation between the concentration level and profitability rates in the banking system of Saudi Arabia. Bhatti \& Hussain (2010) Using regression analysis, they found a positive relationship between concentration ratio $(\mathrm{CR})$ and profitability in Pakistani commercial banks. On the basis of previous research, study set the first hypothesis to find out the relationship between Bank concentrations with bank performance.

$\mathrm{H}_{1}$ : Bank concentration is positively related with bank performance.

From the past studies, market share is one of the important variables that affect the profitability of the firm. Market share is regarded as the index of market structure of the bank. RMP hypothesis states that the banks with relatively larger market share and a range of differentiated product lines are better able to exercise their market power to gain superior profit. RMP emphasize excess profit deriving from larger banks' individual market share but not necessarily from collusive behaviors (Pradhan \& Gajurel, 2011). The study develops the hypothesis on the following manner to support the objective of the study.

\section{$\mathrm{H}_{2}$ : There is positive relationship between market share and performance of the bank.}

Furthermore Efficient Structure (ES) theory also includes two hypothesis x-efficiency and scale efficiency. $\mathrm{X}$-efficiency hypothesis explain that market concentration is resulted from the efficiency of the bank. Consequently, bank's higher profit is derived from operational efficiency. Similarly The scale efficiency hypothesis, emphasize more on the level of scale economies. The banks operating at scale efficient level have lower cost per unit which helps to increase profitability. Pradhan \& Gajurel (2011) found that there is weak support for efficiency structure hypotheses. Tan \& Floros (2013) reveals that higher efficiency leads to higher market power for Chinese banks. The study examines the following hypothesis on the base of the theories and past studies.

\section{$\mathrm{H}_{3}$ : There is positive relationship between efficiency} score and performance.

There are many existing studies that investigate the effects of foreign ownership on the efficiencies or stabilities of host country banking industry (Claessens, et al., 2000; Claeys \& Hainz, 2007). Many cross-country and case studies, suggest that foreign banks are more efficient than their domestic competitors in developing countries (O'Sullivan, 2012). It is pointed out that foreign ownership could help to increase the soundness and stability of the banking system of the host country because foreign banks are known to have superior business resources and strategies and conduct more active and aggressive risk management and stability oriented businesses. Ownership structure is measured by dummy variable taking value of 0 for foreign joint venture banks and 1 for local private banks in this research study. This study is going to test the following hypothesis on the basis of previous literature.

\section{$\mathrm{H}_{4}$ : Foreign ownership positively impacts bank performance.}

\section{Data and Methodology}

The study attempts to empirically investigate the relationship between market structure and performance of the Nepalese commercial banks over the study period of 2011-2015 using causal research design. The study is based on secondary source of data obtained from published annul reports of the sample banks. The stratified sampling technique has been employed to select sample banks which include 10 commercial banks comprising 5 joint venture and 5 local private banks. The public sector banks have been excluded from the study. The purposively selected joint venture banks are Everest bank Limited (EBL), Nepal SBI bank (NSBI), Nabil bank (NABIL), Nepal Bangladesh bank (NBBL), and Himalyan bank Limited (HBL). Similarly 
local private banks are Nepal investment bank (NIB), Laxmi Bank (LBL), Kumari Bank (KBL), Sunrise bank Limited (SUNBL) and Siddhartha bank Limited (SBL). To examine the relationship between banking market structure and performance, a pooled OLS model is specified, and then the indicators of market structure are used as explanatory variables in the regression model. The regression model used in the study has the following specification:

$R O A_{i, t}=\alpha_{0}+\beta_{1} \operatorname{CONC}_{i, t}+\beta_{2} M S_{i, t}+\beta_{3} E S_{i, t}+\beta_{4} O W N_{i, t}$ $+\varepsilon_{i, t}$

Where, ROA is the dependent variable representing bank performance. CONC is market performance measured by Herfindahl Hirschman Index (HHI), MS is market share in terms of deposits, ES is efficiency score computed using DEA and OWN is a dummy variable representing joint venture banks with foreign ownership and local private banks with dichotomous value of 0 and 1 respectively. The subscript $\mathrm{i}$ represents $i^{\text {th }}$ bank and the subscript $t$ represents $t^{\text {th }}$ year in the study period. $\varepsilon_{i t}$ is the residual error.

\section{Bank Efficiency Measure}

Data Envelopment analysis (DEA) is used in the study which is non-parametric approach based on sample data to measure the efficiency of sample banks. DEA has proven to be a popular technique for efficiency analysis in general, and in the financial services industry in particular. DEA optimizes on each individual observation with the objective of calculating a discrete piecewise linear frontier determined by the set of Pareto-efficient decision making units (DMUs) which are the sample A-class financial institutions in the study. Using this frontier, DEA computes a maximal performance measure for each DMU relative to all other DMUs. The study uses CCR input-oriented variable returns to scale DEA model to reduce the multiple-input, multiple-output situation for each bank to a scalar measure of efficiency. Staff expenses and interest expenses are taken as inputs while investment and loan are taken as output for the purpose of this analysis. Efficiency scores vary between 0 and 1 , with 1 representing fully efficient DMU. The efficiency scores are calculated as follows:

$$
\begin{gathered}
\max E F F k=\left(\sum u_{r k} y_{r k}\right) /\left(\sum v_{i k} x_{i k}\right) \ldots \ldots . .(2) \\
\text { Subject to }:\left(\sum u_{r k} y_{r j}\right) /\left(\sum v_{i k} x_{i j}\right)<1 ; j=1, \ldots, \mathrm{n} . \\
\sum u_{r k}>\in ; r=1, \ldots, \mathrm{s} . \\
\sum \mathrm{v}_{\mathrm{ik}}>\in ; i=1, \ldots, \mathrm{m} . \\
\in>0 .
\end{gathered}
$$

Where $\max \mathrm{EFF}_{\mathrm{k}}$ means maximize efficiency of bank $\mathrm{k}$. This model evaluates the relative efficiency of bank $k$ based on the performance of $j=1, \ldots, n$ banks in the population, where the $y r j$ and $x i j$ variables in the model represent the observed amounts of the $r$ th output and the $i$ th input, respectively, of the $j$ th bank.

\section{Herfindahl-Hirschman Index (HHI)}

HHI is the most widely used measure of concentration and a proxy for competition in theoretical research and empirical analysis. It is the sum of the squares of market shares of all the banks and has the following form:

$$
\mathrm{HHI}_{\mathrm{t}}=\sum_{\mathrm{i}=1}^{\mathrm{N}} \mathrm{S}_{\mathrm{it}}^{2}
$$

Where, $\mathrm{S}_{\mathrm{it}}$ is the market share of bank $\mathrm{i}$ in year $\mathrm{t}$ and $\mathrm{N}$ is the total number of banks in the system. In calculating market shares, total assets have been taken as a measure of bank size. Contrary to the n-bank concentration ratios, in the calculation of HHI, all banks in the market are taken into account. HHI stresses the importance of larger banks by giving them a higher weight than smaller banks. Larger value of HHI indicates larger concentration or less competition and vice-versa.

\section{Empirical Analysis}

As far as the bank efficiency is concerned, the study focus on the DEA efficiency scores of Nepalese commercial banks in our sample, then the structure -performance relationship is analyzed latter for the period 2011-2015. The mean values of efficiency scores are presented in Table I.

Table I shows the sampled 10 commercial bank's respective average efficiency score. Average efficiency score of the sample banks during the period 20112015 is estimated at 0.86178 . This result reflected that inefficiency cost is on average around 0.138282 that indicates a waste of resources in the Nepalese banks which is very low. 
Table I: Efficiency Scores During the Period 2011-2015

\begin{tabular}{lclc}
\hline \multicolumn{2}{c}{ Joint venture banks } & \multicolumn{2}{c}{$\begin{array}{c}\text { Non- joint venture banks } \\
\text { (local private banks) }\end{array}$} \\
\hline Banks & $\begin{array}{c}\text { Scale } \\
\text { efficiency }\end{array}$ & Banks & $\begin{array}{c}\text { Scale } \\
\text { efficiency }\end{array}$ \\
\hline EBL & 0.98008 & NIB & 0.98606 \\
NSBI & 0.97874 & LBL & 0.74532 \\
NABIL & 0.97244 & KBL & 0.74592 \\
NBBL & 0.72502 & SUNBL & 0.6826 \\
HBL & 0.9643 & SBL & 0.8367 \\
Average & 0.924116 & & 0.79932 \\
\hline Scale efficiency & & 0.86178 & \\
average & & & \\
\hline
\end{tabular}

Generally efficiency measurement highlights the approach banks allocate their resources that specify the degree of adjustment between incurred costs and the quality of the offered services. Accordingly, efficiency scores 0.86178 of Nepalese commercial banks relates to the two inputs-outputs DEA model, which implies that the competence of the bank to conveniently support the used resources to the products. The evidence indicates that the Nepalese banks are efficient in undertaking their financial intermediation role of deposit mobilization into loans and investments. Similarly the average efficiency score of joint venture banks is higher as compared to local private banks which imply that the resource mobilization efficiency of joint venture banks is relatively higher.

Table II: Mean Scores of Variables of Joint Venture and Non-joint Venture Banks

\begin{tabular}{lcc}
\hline $\begin{array}{c}\text { Vari- } \\
\text { ables }\end{array}$ & $\begin{array}{c}\text { Joint venture } \\
\text { bank }\end{array}$ & $\begin{array}{c}\text { Non joint venture } \\
\text { bank }\end{array}$ \\
\hline ROA & 2.036 & 1.3379 \\
CONC & 0.1189 & 0.1189 \\
MS & 0.1201 & 0.0799 \\
DEA & 0.9241 & 0.7993 \\
\hline
\end{tabular}

Table II, presents the descriptive statistics for the data used in this study. Mean score of ROA are 2.036 and 1.3379 of Joint venture bank and non-joint venture bank respectively. Results shows that the average profitability (ROA) of joint venture banks is greater than the non joint venture bank that shows joint venture banks are better in terms of profitability. Regarding MS, mean score of Joint venture bank and non- joint bank are 0.1201 and 0.0799 respectively which reveals that joint venture banks have higher share of deposits. Similarly mean value of DEA
Score are 0.9241 and 0.7993 of joint venture and nonjoint venture bank. Regarding MS and DEA scores table presents that mean scores of joint venture banks of the given variables are higher than non joint-venture banks. Whereas MS is the ratio of total bank deposit of each in relation to the sum total of all deposit banks in the sample. Mean value of MS Shows that joint venture banks occupied the larger market share. Likewise mean score of DEA indicates that joint venture banks are more efficient than the private local banks. The HerfindahlHirschman index (HHI) uses the market shares as the main variable to measure the concentration (CONC). It is defined as the sum of the squares of the share of each bank in the market. It is same for all banks at a time. HHI scores lies in between 0 to 1 . HHI scores are in decreasing order and it indicates that Nepalese commercial banks are becoming less concentrated and more competitive. That's why mean value of CONC for joint venture and non joint venture is same here.

Table III: Correlation Matrix

\begin{tabular}{lllll}
\hline & ROA & CONC & MS & $\begin{array}{l}\text { DEA } \\
\text { Score }\end{array}$ \\
\hline ROA & 1 & & & \\
CONC & -0.219 & 1 & & \\
MS & 0.238 & .00 & 1 & \\
DEA Score & -0.137 & -0.023 & 0.018 & 1 \\
\hline${ }^{* * *}$ means the correlation is significant at $5 \%$ and $1 \%$ \\
level of significance respectivley
\end{tabular}

Table III, presents the Pearson correlation coefficient matrix of the variables used in the study. Correlation value between ROA and CONC is -0.219 . This indicates that ROA is inversely associated with CONC. Similarly correlation value between ROA and MS is 0.238 that shows ROA is positively correlated with MS that suggest profitability of the Nepalese commercial banks is increased as the market share of the bank is increased. On the other hand, correlation value between ROA and DEA Score is -0.137 it means ROA is inversely correlated with DEA Score that implies as the DEA Score is increased ROA is decreased in Nepalese commercial banks. This result is in contrary to the theoretical literature. The relationship between the variables is analyzed in the following section using pooled OLS regression model. 
Table IV: Output of Regression Model

\begin{tabular}{|c|c|c|c|c|}
\hline & Coefficients & $\begin{array}{l}\text { Std. Er- } \\
\text { ror }\end{array}$ & t-stat & p-values \\
\hline Constant & 11.929 & 6.538 & 1.825 & 0.075 \\
\hline CONC & $-87.505^{*}$ & 54.916 & -1.593 & 0.100 \\
\hline MS & $4.498^{*}$ & 2.605 & 1.727 & 0.091 \\
\hline ES & -0.0001 & 0.000 & -1.050 & 0.299 \\
\hline OWN & $-0.548^{* *}$ & 0.231 & -2.370 & 0.022 \\
\hline $\mathrm{R}^{2}$ & 0.287 & & & \\
\hline Adj $R^{2}$ & 0.224 & & & \\
\hline F-stat & $4.539^{* * *}$ & & & \\
\hline
\end{tabular}

Table IV presents the output of the pooled OLS regression model. The results reveal that the explanatory variables market concentration; market share and ownership have significant relationship with the dependent variable bank profitability. The coefficient of CONC is negative and $t$ value of CONC is -1.593 which is statistically significant at 10 percent level. Similarly HHI score which is used to measure the CONC are in decreasing order and it indicates that Nepalese commercial banks are becoming less concentrated and more competitive. The study is majorly concerned with the relationship between performance and market structure variables, especially the HHI. In Table IV, the negative sign of concentration indicates that decreases in the concentration increases the performance of the bank. Similarly HHI indicates that higher concentration in the banking industry impacts bank performance negatively. Result suggests that there is the inverse relationship between ROA and CONC variable which implies that concentration is less beneficial in term of profitability of the banks. Market share is used to reflect bank individual's market power. The coefficient of MS is positive and t value of MS is 1.727 which is statistically significant at 10 percent level of significance. However, MS is based on total deposit. This evidence suggests that market share has positive influence on profitability. The result reveals that higher market power of the banks in terms of higher deposit market share results in improved profitability.

Similarly, the coefficients of dummy variable for ownership structure (OWN) that is statistically significant and negatively correlated with the performance of Nepalese commercial banks. Results indicates that, ROA varies depends on bank ownership types. The foreign ownership in the banks is found to positively impact bank performance. This can be explained by the fact that the profitability of these banks is favored by the shareholding by joint venture institutions that may be due to trained staff and with significant management capabilities.

Finally, the coefficient of efficiency score variable is insignificant. The result reveals that the scale efficiency of the banks doesn't impact bank's financial performance. It indicates that profitability of Nepalese commercial banks is not driven by the efficiency of managing input and output. In other words, the scale efficiency in financial intermediation doesn't effects bank's profitability position. Overall, the F value is 4.539 and significant which indicate that model is has good fit and the R-squared value indicates that around 30 percentage of variation in the bank profitability is explained by the banking industry market structure.

This paper empirically investigated relationship between market structure and performance of the Nepalese commercial banks. To analyze the relationship between market structure and performance of the bank different hypothesis are developed in the present study. According to the regression results market concentration is negatively significant. Thus empirical results of the study show that null hypothesis is accepted. According SCP theory higher market concentration impairs the competition but increases the performance (Pradhan \& Gajurel, 2011). In the context of Nepalese commercial banks, during the sample period study doesn't support SCP theory. This indicates that result is opposite to the SCP hypothesis. Study concluded that Nepalese commercial banks are more profitable when market is more competitive.

On the other hand, market share is positively significant. This indicates that alternative hypothesis is accepted. This evidence suggests that market power has positive influence on profitability. The empirical results of the study support the Relative market power hypothesis which better explain the relationship between market 
structure and performance of the bank in the context of Nepalese commercial banks. Therefore, larger Nepalese banks earn higher profits.

Similarly, the empirical result of the study showed that efficiency score is statistically insignificant. It means null hypothesis is accepted in the study. Evidence indicated that there is no relationship between the efficiency and performance in Nepalese commercial banks which is opposite to the efficiency structure theory. The result indicates that, more efficient banks are unable to make more profit. The reason behind this may be the shorter sample period and low number of sample of the study as well as selection of input and output for the study to assess the DEA efficiency score.

As far as ownership structure is concerned, alternative hypothesis is accepted in the study that stated profitability varies with ownership type. That depicts Joint venture banks are more profitable than local private banks. That may be caused due to the large market share held by the Joint venture banks in Nepal.

\section{Conclusion}

This study empirically investigated relationship between market structure and performance of the Nepalese commercial banks. Descriptive analysis of the study concluded that joint venture banks (JVC) are better in terms of profitability. In the same way JVC are able to occupy larger market share and seems more efficient. The study revealed that decrease in market concentration

\section{References}

Ayadi, I., \& Ellouze, A. (2013). Market Structure and Performance of Tunisian Banks. International Journal of Economics and Financial Issues , 3 (2), 345-354.

Bamakhramah, A. S. (1992). Measurement of Banking Structure in Saudi Arabia and Its Effect on Bank. J. KAU: Econ. \& Adm. , 5, 3-29.

Bhatti, G. A., \& Hussain, H. (2010). Evidence on Structure Conduct Performance Hypothesis In Pakistani. International Journal of Business and Management , 5 (9). increases the bank profitability in the context of Nepalese commercial banks. On the other hand, study results indicated that market power has positive influence on profitability. Therefore, larger Nepalese banks earn higher profits. On the contrary, empirical results indicated that there is no relationship between the bank's efficiency and performance in Nepalese commercial banks. The result indicates that, more efficient banks are unable to make more profit. In the context of ownership structure of the bank, results indicate that, ROA differences depend on bank ownership types. Profitability of joint venture bank is larger than local private banks in Nepal.

The empirical results of this study have a number of policy and managerial applications. As the results of the study market concentration is negatively related with performance of the bank so that Policy makers should concentrate on policies that promotes market competition in banking industry and making less market concentration. Similarly Policy maker should focus on promoting foreign investment on banking industry as the study concluded that Profitability of joint venture bank is larger than local private banks in Nepal. Likewise study recommend for further study that can be conducted with larger sample size along with larger time period. Further research can conduct on longitudinal study (i.e before and after liberalization). Moreover researcher can conduct research using DEA efficiency score using intermediation approach and output orientation that may change the result.

Claessens, S., Djankov, S., \& Lang, L. (2000). The separation of ownership and control in East Asian corporations. Journal of Financial Economics, 58, 81-112.

Claeys, S., \& Hainz, C. (2007). Acquisition versus greenfield: The impact of the mode of foreign bank entry on information and bank lending rates. International Review of Finance, 3, 105-29.

González, F. ( 2009). Determinants of Bank-Market 
Structure: Efficiency and Political Economy Variables. Pradhan, R. S., \& Gajurel, D. P. (2011). StructureJournal of money credit and banking , 41 (4), $735-754$.

Kharel, R. S., \& Pokhrel, D. R. (2012). Does Nepal's

Financial Structure Matter for Economic Growth. NRB Economic Review .

Mensi, S., \& Zouari, A. (2010). Efficient Structure versus Market Power: Theories and Empirical Evidence. International Journal of Economics and Finance , 2 (4).

O'Sullivan, J. A. (2012). Corporate governance, performance and risk-taking in the $U . S$. banking industry (Doctoral dissertations, University of New Orleans). Retrieved from ProQuest Dissertations and Theses Database. (UMI No. 3531151) Performance Relation in Nepalese Banking Industry. International Conference on Economics, Business , 2.

Tan, Y., \& Floros, C. (2013). Market power, stability and performance in the Chinese banking industry. Economic Issues , 18 (2).

Thapa, M. (2010). Competitive Strategy and Performance of. PYC Nepal Journal of Management, 3 (1).

Ugwunta, D. O., Ani, W. U., Ugwuanyi, G. O., \& Ugwu, J. N. (Eds.). (2012). Journal of Economics and Sustainable Development, 3 (7).

Zhengchao, L., \& Qin, L. (Eds.). (2012). China Banking Market Structure and Performance: Based on Panel Data 2000-2010. International Business and Management , 5 (2). 